\title{
Impact of Preoperative Endoscopic Biliary Drainage on Postoperative Outcome after Pancreaticoduodenectomy
}

\author{
Hazem M Zakaria ${ }^{1}$, Nahla K Gaballa ${ }^{2}$, Mohammed Abbas ${ }^{3}$, Osama Elbahr ${ }^{4}$, Talaat Zakareya ${ }^{4}$
}

Corresponding author:

Hazem Mohamed Zakaria, MD

Department of Hepatopancreaticobiliary

\& liver transplantation surgery

National Liver Institute

Menoufia University

32511 Shebin El-koom, Menoufia, Egypt

E-mail: hazemlasheenn@yahoo.com

Tel: +201097071055

Fax: +20482234586

Tel.: +20482222740
'Department of Hepatopancreatobiliary and Liver Transplant Surgery, National Liver Institute, Menoufia University, Menoufia, Egypt

${ }^{2}$ Department of Anesthesia and Intensive Care, National Liver Institute, Menoufia University, Menoufia, Egypt

${ }^{3}$ Department of Diagnostic and intervention radiology, National Liver Institute, Menoufia, Egypt ${ }^{4}$ Department of Hepatology and Gastroenterology, National Liver Institute, Menoufia University, Menoufia, Egypt

\section{ABSTRACT}

Background: The value of preoperative biliary drainage (PBD) on the surgical outcome after pancreaticoduodenectomy (PD) is still a point of controversy. The aim of this study was to identify the impact of biliary drainage (BD) prior to PD on the postoperative outcome.

Methods: The data of patients, who underwent PD from February 2009 to February 2017, were retrospectively studied. A comparison was performed between 2 groups of patients; group $\mathrm{A}$ (with PBD) and group B (without PBD), according to preoperative, operative and postoperative data.

Results: PD was performed in 158 patients with periampullary lesions. Group A, included 76 patients $(48.1 \%)$ while 82 patients were included in group $B(51.9 \%)$. The incidence of major postoperative complications was significantly higher in group $A(P=0.04)$. The infectious complications were higher in group like; positive intraoperative bile culture $(P=0.06)$, intraabdominal abscess $(P=0.07)$ and wound infection $(P=0.04)$. Also, hospital stay and mortality were higher in group $\mathrm{A}(P=0.05$ and 0.08 , respectively). High preoperative bilirubin level was not a risk factor for major postoperative complications $(P=0.12)$.

Conclusion: Patients with PBD had a significantly higher incidence of major postoperative complications mainly of infectious ones, thus PBD should be performed only in selected patients, not as a routine prior PD.

Key words: biliary drainage, pancreaticoduodenectomy, postoperative complications, wound infection

\section{INTRODUCTION}

Periampullary lesions can be the cause of obstructive jaundice (OJ), pancreaticoduodenectomy (PD) being usually the curative choice, especially for malignant obstruction. OJ with high serum bilirubin level is a risk factor for cholangitis, cardiac or liver dysfunction, and coagulation profile affection. Theoretically, biliary drainage (PD) with reduced bilirubin level can improve liver 
function and the outcome after surgery. However, there is still controversy over the use of preoperative biliary drainage (PBD) before PD $(1,2)$.

Some literature showed the improved results of surgery with PBD. Others reported no effect or there was an increase in postoperative complications (infectious complications, delayed gastric emptying, biliary or pancreatic fistula), hospital stay and mortality, with an end result of increasing the cost of surgery. Thus some centres do not recommend PBD to be a routine before resectable tumour and reserve it for severe hyperbilirubinemia or cholangitis (3-5).

Biliary drainage can be done either by endoscopic retrograde cholangiopancreatography (ERCP), endoscopic nasobiliary drainage (ENBD), or percutaneous transhepatic drainage (PTD), with reported different surgical outcomes with the use of each technique (6-8). The aim of this study was to show the effect of preoperative endoscopic biliary drainage (EBD) on postoperative morbidity and mortality after PD surgery.

\section{PATIENTS AND METHODS}

\section{Patients}

A retrospective study was conducted for patients who underwent PD between February 2009 and February 2017 at the National Liver Institute, Menoufia University, Egypt. The data were collected after institutional review board approval.

ERCP was the method of BD in this study. Our patients were divided into 2 groups; group $A$ (with PBD) and group B (without PBD). Patient demographics, preoperative, operative and postoperative clinicopathological data were collected, analyzed and compared between the 2 groups.

\section{Operative Details}

PD was performed for periampullary lesions (either benign or malignant). Classic PD or pyloruspreserving PD (PPPD) were included in the study. Pancreatic anastomosis was performed by pancreaticogastrostomy (PG) or pancreaticojejunostomy (PJ) (either duct to mucosa or jejunal loop invagination). The pancreatic texture was assessed by surgeon experience and pancreatic duct diameter was calculated.

\section{Postoperative follow up}

The early postoperative complications were assessed by the Clavien-Dindo classification of surgical complica- tions (9) from I to V, depending on the main complications of each patient. Complications $\geq$ grade Illa were considered as major complications. Postoperative complications like biliary leakage, postoperative pancreatic fistula (PPF), post pancreatectomy haemorrhage (PPH), and delayed gastric emptying and their grades were defined and classified according to the International Study Group of Pancreatic Surgery (ISGPS) definitions and grading (10-12). The postoperative follow up of the patients was from the day of surgery to February 2018 with a mean follow up period of 43 months.

\section{Statistical Analysis}

The analysis of the data was performed using SPSS version 21.0 (Chicago, IL, USA). The comparison between categorical variables was performed by Fisher's exact test or $\chi^{2}$-test. In continuous variables, the differences between the means were compared by independentsample T-test or Mann-Whitney U test. Independent risk factors for major postoperative complications were assessed in multivariate analysis using linear regression model. Significant $P$ value was considered when $<0.05$.

\section{RESULTS}

Pancreaticoduodenectomy was performed in 158 patients with periampullary lesions (malignant and benign). Group A, included 76 patients (48.1\%) while 82 patients (51.9\%) were included in group B. In group A, 48 patients (63.2\%), underwent biliary drainage before the surgical consultation, mainly the early cases. The indications of ERCP in other patients were a very high bilirubin level affecting liver function, cholangitis, and/or delay in the elective surgery.

The complications after ERCP were: stent dysfunction and pancreatitis in 20 patients (26.3\%), bleeding in 5 patients $(6.6 \%)$ and duodenal perforation in 2 patients (2.6\%); most of these complications delayed the PD operation. The mean duration between PD and the surgery was 5.5 weeks (range, 2-34 weeks).

The two groups were compared regarding the patient demographics, preoperative and operative data (table 1). Univariate analysis presented a significant difference between both groups regarding gender $(P=0.01)$, preoperative total bilirubin level $(P=0.04)$ and operative blood loss $(P=0.03)$. Serum level of carbohydrate antigen (CA) 19.9, and positive lymph nodes (LNs), were higher in group $A$, but without a statistically significant difference $(P=0.07)$.

The overall incidence of postoperative complica- 
Table 1 - Patients characteristics, preoperative, operative and pathological data

\begin{tabular}{|c|c|c|c|}
\hline & PBD $(n=76)$ & No-PBD $(n=82)$ & P-value \\
\hline $\begin{array}{l}\text { Age }(\mathbf{y}) \\
\text { mean } \pm \text { SD } \\
\text { (range) } \\
\text { age }>60\end{array}$ & $\begin{array}{c}55.6 \pm 12 \\
(35-74) \\
33(43.4 \%)\end{array}$ & $\begin{array}{c}57.1 \pm 13.6 \\
(20-75) \\
39(47.6 \%)\end{array}$ & 0.63 \\
\hline Male Gender & $49(64.5 \%)$ & $33(40.2 \%)$ & 0.01 \\
\hline $\begin{array}{l}\text { Body mass index }\left(\mathrm{kg} / \mathrm{m}^{2}\right) \\
\leq 25 \\
>25\end{array}$ & $\begin{array}{l}36(47.4 \%) \\
40(52.6 \%)\end{array}$ & $\begin{array}{l}38(46.3 \%) \\
44(53.7 \%)\end{array}$ & 0.87 \\
\hline $\begin{array}{l}\text { Co-morbidities (yes) } \\
\text { DM } \\
\text { HTN } \\
\text { Cardiovascular disease }\end{array}$ & $\begin{array}{l}48(63.2 \%) \\
39(51.3 \%) \\
29(38.2 \%) \\
13(17.1 \%)\end{array}$ & $\begin{array}{c}47(57.3 \%) \\
40(48.8 \%) \\
32(39 \%) \\
17(20.7 \%)\end{array}$ & $\begin{array}{l}0.12 \\
0.52 \\
0.83 \\
0.33\end{array}$ \\
\hline $\begin{array}{l}\text { Main symptoms } \\
\text { Jaundice } \\
\text { Abdominal pain } \\
\text { Nausea/vomiting } \\
\text { Loss of weight }\end{array}$ & $\begin{array}{l}58(76.3 \%) \\
31(40.8 \%) \\
24(31.6 \%) \\
40(52.6 \%)\end{array}$ & $\begin{array}{l}36(43.9 \%) \\
44(53.7 \%) \\
26(31.7 \%) \\
39(47.6 \%)\end{array}$ & $\begin{array}{l}0.01 \\
0.11 \\
1.0 \\
0.35\end{array}$ \\
\hline $\begin{array}{l}\text { Prestenting total bilirubin }(\mathbf{m g} / \mathrm{dl}) \\
\text { mean } \pm S D \\
\text { (range) }\end{array}$ & $\begin{array}{l}12.3 \pm 6.2 \\
(5.4-38)\end{array}$ & $\begin{array}{l}4.8 \pm 7.1 \\
(0.6-16)\end{array}$ & 0.01 \\
\hline $\begin{array}{l}\text { Preoperative total bilirubin (mg/dl) } \\
\text { mean } \pm S D \\
\text { (range) }\end{array}$ & $\begin{array}{c}3.3 \pm 4.3 \\
(0.5-13.6)\end{array}$ & $\begin{array}{l}4.8 \pm 7.1 \\
(0.6-16)\end{array}$ & 0.04 \\
\hline $\begin{array}{l}\mathrm{ALT}(\mathrm{U} / \mathrm{L}) \\
\text { mean } \pm \mathrm{SD} \\
\text { (range) }\end{array}$ & $\begin{array}{c}47 \pm 27 \\
(24-153)\end{array}$ & $\begin{array}{c}58 \pm 29 \\
(28-165)\end{array}$ & 0.12 \\
\hline $\begin{array}{l}\text { Albumin }(\mathbf{g} / \mathbf{d l}) \\
\text { mean } \pm S D \\
\text { (range) }\end{array}$ & $\begin{array}{l}3.5 \pm 0.5 \\
(2.9-4.4)\end{array}$ & $\begin{array}{l}3.6 \pm 0.5 \\
(3-4.8)\end{array}$ & 0.38 \\
\hline $\begin{array}{l}\text { White blood cells }\left(\times 10^{9} / \mathrm{L}\right) \\
\text { mean } \pm S D \\
\text { (range) }\end{array}$ & $\begin{array}{l}7.8 \pm 2.2 \\
(4-12.6)\end{array}$ & $\begin{array}{c}6.5 \pm 2.7 \\
(5-13)\end{array}$ & 0.17 \\
\hline $\begin{array}{l}\text { CA 19-9 }(\mathrm{U} / \mathrm{mL}) \\
\text { mean } \pm \mathrm{SD} \\
\text { (range) } \\
\text { normal } \\
\text { high }\end{array}$ & $\begin{array}{l}1568 \pm 6373 \\
(13-37530) \\
34(44.7 \%) \\
42(55.3 \%)\end{array}$ & $\begin{array}{c}177 \pm 312 \\
(8-2000) \\
40(48.8 \%) \\
42(51.2 \%)\end{array}$ & 0.09 \\
\hline $\begin{array}{l}\text { Pancreatic texture } \\
\text { Firm } \\
\text { soft }\end{array}$ & $\begin{array}{l}39(51.3 \%) \\
37(48.7 \%)\end{array}$ & $\begin{array}{l}38(46.3 \%) \\
44(53.7 \%)\end{array}$ & 0.18 \\
\hline $\begin{array}{l}\text { Type of pancreatic reconstruction } \\
\text { Pancreaticogastrostomy } \\
\text { Pancreaticojejunostomy } \\
\text {-invagination } \\
\text {-duct to mucosa }\end{array}$ & $\begin{array}{l}15(19.7 \%) \\
61(80.3 \%) \\
28(45.9 \%) \\
33(54.1 \%)\end{array}$ & $\begin{array}{c}8(9.8 \%) \\
74(90.2 \%) \\
39(52.7 \%) \\
35(47.3 \%)\end{array}$ & 0.15 \\
\hline $\begin{array}{l}\text { Vascular reconstruction } \\
\text { yes }\end{array}$ & $9(11.8 \%)$ & $10(12.2 \%)$ & 1.0 \\
\hline $\begin{array}{l}\text { Operative time (min) } \\
\text { mean } \pm S D \\
\text { (range) }\end{array}$ & $\begin{array}{c}410 \pm 110 \\
(250-670)\end{array}$ & $\begin{array}{l}365 \pm 125 \\
(240-550)\end{array}$ & 0.16 \\
\hline $\begin{array}{l}\text { Operative blood loss } \\
\text { mean } \pm S D \\
\text { (range) }\end{array}$ & $\begin{array}{c}900 \pm 550 \\
(250-2500)\end{array}$ & $\begin{array}{c}600 \pm 500 \\
(200-2000)\end{array}$ & 0.03 \\
\hline $\begin{array}{l}\text { Blood transfusion (unit) } \\
\text { mean } \pm S D \\
\text { (range) }\end{array}$ & $\begin{array}{c}1 \pm 2 \\
(0-8)\end{array}$ & $\begin{array}{c}1 \pm 1 \\
(0-6)\end{array}$ & 0.46 \\
\hline $\begin{array}{l}\text { Pathological diagnosis } \\
\text { Malignant } \\
\text { Benign }\end{array}$ & $\begin{array}{l}59(77.6 \%) \\
17(22.4 \%)\end{array}$ & $\begin{array}{l}59(72 \%) \\
23(28 \%)\end{array}$ & 0.46 \\
\hline $\begin{array}{l}\text { Pathological site } \\
\text { Pancreas } \\
\text { Ampullary } \\
\text { Duodenum } \\
\text { CBD }\end{array}$ & $\begin{array}{l}49(64.5 \%) \\
16(21.1 \%) \\
2(2.6 \%) \\
9(11.8 \%)\end{array}$ & $\begin{array}{c}57(69.5 \%) \\
18(22 \%) \\
5(6.1 \%) \\
2(2.4 \%)\end{array}$ & 0.09 \\
\hline
\end{tabular}




\begin{tabular}{|c|c|c|c|}
\hline $\begin{array}{l}\text { Pathological tumour type } \\
\text { PDAC } \\
\text { Ampullary adenocarcinoma } \\
\text { Cholangiocarcinoma } \\
\text { NET } \\
\text { IPMN } \\
\text { Cystic tumour } \\
\text { Other types }\end{array}$ & $\begin{array}{c}33(43.4 \%) \\
16(21.1 \%) \\
8(10.5 \%) \\
3(3.9 \%) \\
3(3.9 \%) \\
3(3.9 \%) \\
10(13.3 \%)\end{array}$ & $\begin{array}{c}30(36.6 \%) \\
18(22 \%) \\
2(2.4 \%) \\
5(6.1 \%) \\
5(6.1 \%) \\
7(8.5 \%) \\
15(18.3 \%)\end{array}$ & 0.13 \\
\hline $\begin{array}{l}\text { Tumour differentiation in malignant cases } \\
\text { ( } \mathrm{n}=59 \text { for each group) } \\
\text { Well } \\
\text { Moderate } \\
\text { Poor }\end{array}$ & $\begin{array}{l}14(23.7 \%) \\
31(52.6 \%) \\
14(23.7 \%)\end{array}$ & $\begin{array}{c}10(17 \%) \\
32(54.2 \%) \\
17(28.8)\end{array}$ & 0.25 \\
\hline $\begin{array}{l}\text { Maximum tumour diameter } \\
\text { Mean } \pm S D \\
\text { (Range) }\end{array}$ & $\begin{array}{l}3.3 \pm 2.2 \\
(1.3-9)\end{array}$ & $\begin{array}{c}3.1 \pm 2.6 \\
(1.5-8)\end{array}$ & 0.34 \\
\hline $\begin{array}{l}\text { Positive LNs } \\
\text { Mean } \pm \text { SD } \\
\text { (Range) } \\
\text { yes }\end{array}$ & $\begin{array}{c}2 \pm 1 \\
(0-8) \\
32 / 59(45.2 \%)\end{array}$ & $\begin{array}{c}1 \pm 2 \\
(0-4) \\
22 / / 59(37.3 \%)\end{array}$ & 0.07 \\
\hline
\end{tabular}

tions was higher in group A (table 2), with a significant statistical difference in major postoperative complications $(P=0.04)$. The infectious postoperative complications were higher in group A including: positive intraoperative bile culture [mainly for Escherichia coli (E-coli) and Klebsiellapneumoniae], intra-abdominal abscess (IAA) formation ( $P=0.07)$, however without a statistical significant difference, and wound infection (WI) $(P=0.04)$. Delayed gastric emptying was significantly different between both groups $(P=0.03)$. In group $A$, hospital stay

Table 2 - postoperative data and complications

\begin{tabular}{|c|c|c|c|}
\hline Variables & PBD $(n=76)$ & No-PBD $(n=82)$ & P-value \\
\hline Clavien-Dindo classification of surgical complications & & & 0.29 \\
\hline 0 & $16(21.1 \%)$ & $21(25.6 \%)$ & \\
\hline 1 & $16(21.1 \%)$ & $18(22 \%)$ & \\
\hline$\|$ & $20(26.3 \%)$ & $28(34.1 \%)$ & \\
\hline Illa & $9(11.8 \%)$ & $7(8.5 \%)$ & \\
\hline IIIb & $4(5.3 \%)$ & $3(3.7 \%)$ & \\
\hline IVa & 0 & $1(1.2 \%)$ & \\
\hline $\mathrm{IVb}$ & $2(2.6 \%)$ & $2(2.4 \%)$ & \\
\hline V & $9(11.8 \%)$ & $2(2.4 \%)$ & \\
\hline Post operative major complications ( $\geq$ Illa) & $24(31.6 \%)$ & $15(18.3 \%)$ & 0.04 \\
\hline \multicolumn{4}{|l|}{ Post operative main complications } \\
\hline - intra-abdominal abscess & $11(14.5 \%)$ & $3(3.7 \%)$ & 0.07 \\
\hline - pancreatic fistula & $13(17.1 \%)$ & $11(13.4 \%)$ & 0.25 \\
\hline$A$ & 8 & 5 & \\
\hline B & 3 & 4 & \\
\hline C & 2 & 2 & \\
\hline - delayed gastric emptying & $8(10.5 \%)$ & $18(22 \%)$ & 0.03 \\
\hline$A$ & 4 & 10 & \\
\hline $\mathrm{B}$ & 2 & 5 & \\
\hline C & 2 & 3 & \\
\hline - postpancreatectomy haemorrage & $4(5.3 \%)$ & $6(7.3 \%)$ & 0.77 \\
\hline$A$ & 0 & 1 & \\
\hline B & 2 & 3 & \\
\hline C & 2 & 2 & \\
\hline
\end{tabular}




\begin{tabular}{|c|c|c|c|}
\hline - wound infection & $21(27.6 \%)$ & $13(15.9 \%)$ & 0.04 \\
\hline - biliary fistula5(6.6\%) & $3(3.7 \%)$ & 0.18 & \\
\hline - gastric fistula & $3(3.9 \%)$ & $1(1.2 \%)$ & 0.48 \\
\hline - Positive bile culture & $11 / 43(25.6 \%)$ & $3 / 22(13.6 \%)$ & 0.06 \\
\hline - medical complications (pulmonary, cardiac, renal,...) & $15(19.7 \%)$ & $9(11 \%)$ & 0.15 \\
\hline Reoperation & $8(10.5 \%)$ & $5(6.1 \%)$ & 0.14 \\
\hline ICU stay (days) & & & 0.25 \\
\hline mean $\pm S D$ & $5 \pm 5$ & $3 \pm 6$ & \\
\hline (range) & $(0-18)$ & $(0-11)$ & \\
\hline Hospital stay (days) & & & 0.05 \\
\hline mean $\pm S D$ & $14 \pm 11$ & $10 \pm 7$ & \\
\hline (range) & $(8-58)$ & $(6-43)$ & \\
\hline Rehospitalization in first $3 \mathrm{~ms}$ & $4(5.3 \%)$ & $2(2.4 \%)$ & 0.25 \\
\hline Hospital mortality & $9(11.8 \%)$ & $2(2.4 \%)$ & 0.08 \\
\hline Recurrence of tumour & $15 / 59(25.4 \%)$ & $19 / 59(32.2 \%)$ & 0.29 \\
\hline
\end{tabular}

was significantly higher $(P=0.05)$, and also hospital mortality, but without a statistical significant difference $(P=0.08)$.

The risk factors for postoperative major complications (table 3) were: $\mathrm{PBD}(P=0.03)$, the high serum level of CA19.9 $(P=0.03)$, soft pancreatic texture $(P=0.02)$, operative blood loss $(P=0.01)$, perioperative blood transfusion $(P=0.03)$, positive $\mathrm{LNs}$ in histopathology $(P=0.04)$. In multivariate analysis the independent risk factors for major postoperative complications were high CA19.9 ( $P=0.034)$ (HR=1.2; 95\% Cl: 0.82-1.7), and operative blood loss $(P=0.042)$ (HR=1.0; 95\% Cl: 0.92-1.1). High preoperative bilirubin level ( $>15 \mathrm{mg} / \mathrm{dl})$ was not a risk factor for major postoperative complications ( $P=0.12)$.

The hospital mortality rate was as follows: in patients with PBD $11.8 \%$, and in patients without PBD $2.4 \%$ $(P=0.08)$.

\section{DISCUSSION}

Patients with OJ have a high risk of bacterial translocation with endotoxemia and inflammatory cascades which can alter the cardiac, hepatic or renal function $(1,13)$.

Whether to perform or not PBD for patients with OJ is still a debatable point. Many retrospective and prospective literature studies discussed this issue with different conclusions (13-15). Experimental studies had shown that reduction of serum bilirubin level can improve the liver and immune system function with correction of the coagulation profiles $(15,16)$. Liu et al, showed that serum bilirubin did not significantly affect postoperative complications after PD (17) as reported in our study. In contrast, Smith et al reported that the high preoperative bilirubin level had negative feedback on early postsurgical outcome (18). The threshold level of bilirubin which may need PBD for better prognosis after surgery is still in need of further large volume studies. In this study bilirubin level $>15 \mathrm{mg} / \mathrm{dl}$ has no negative impact on postoperative complications.

Several early retrospective and meta-analysis studies comparing preoperative biliary stenting or the lack of it showed that there was no difference in postoperative outcome regarding different complications or hospital mortality $(19,20)$. But later meta-analyses showed the increased incidence of infectious complications $(6,14)$ as shown in our study. Some studies noticed that nearly $42-79 \%$ of patients with PBD underwent the drainage procedure by the gastroenterologist before evaluation or consultation of the surgeon $(13,21)$, as seen in our early cases, but in last 3 years of this study there was established OJ meeting and board for discussion of these patients with OJ and selection of the proper management plan for each case.

Singhirunnusorn et al, proved a no significant difference in mild and major complications of patients with PBD (42\% and 37\%, respectively) in comparison to (35\% and $32.8 \%$ respectively) in patients without PBD. They also reported no significant difference in hospital mortality, and each complication alone like biliary fistula, pancreatic fistula, WI, and reoperation $(22,23)$. In contrast to our study with a significant difference in major complications, but maybe the definition of major complications that made these changes of results between the different studies. Liu et al, also reported no significant difference in any of the complications between both groups of patients with PBD and without PBD with moderate increase of; positive bile culture (12.8\% vs $5.9 \%$, respectively), IAA (17\% vs $11.8 \%)$ and 
Table 3 - Potential risk factors for major postoperative complications

\begin{tabular}{|c|c|c|c|}
\hline & $\begin{array}{c}\text { Major complications } \\
(\mathrm{n}=39)\end{array}$ & $\begin{array}{c}\text { No and minor } \\
\text { complications }(\mathrm{n}=119)\end{array}$ & P-value \\
\hline age $>60$ & $22(56.4 \%)$ & $50(42 \%)$ & 0.12 \\
\hline Male Gender & $16(41 \%)$ & $66(55.5 \%)$ & 0.08 \\
\hline Body mass index $\left(\mathrm{kg} / \mathrm{m}^{2}\right)>25$ & $24(61.5 \%)$ & $60(50.4 \%)$ & 0.27 \\
\hline Co-morbidities (yes) & $25(66.7 \%)$ & $70(58.8 \%)$ & 0.7 \\
\hline $\begin{array}{l}\text { Preoperative total bilirubin (mg/dl). } \\
\text { mean } \pm S D\end{array}$ & $1.8 \pm 1.9$ & $3.8 \pm 4.6$ & 0.07 \\
\hline Total bilirubin $>15 \mathrm{mg} / \mathrm{dl}$ & $3(7.7 \%)$ & $21(17.6 \%)$ & 0.12 \\
\hline Preoperative biliary drainage & $25(64.1 \%)$ & $51(42.9 \%)$ & 0.03 \\
\hline $\begin{array}{l}\mathrm{ALT}(\mathrm{U} / \mathrm{L}) \\
\text { mean } \pm \mathrm{SD}\end{array}$ & $52 \pm 29$ & $49 \pm 36$ & 0.31 \\
\hline $\begin{array}{l}\text { Albumin }(\mathrm{g} / \mathrm{dl}) \\
\text { mean } \pm \mathrm{SD}\end{array}$ & $3.5 \pm 0.6$ & $3.7 \pm 0.5$ & 0.42 \\
\hline White blood cells $\left(\times 10^{9} / \mathrm{L}\right)$ & $8.2 \pm 2.6$ & $7.5 \pm 1.8$ & 0.23 \\
\hline $\begin{array}{l}\mathrm{CA} 19-9(\mathrm{U} / \mathrm{mL}) \\
\text { mean } \pm \text { SD }\end{array}$ & $2109 \pm 8468$ & $427 \pm 1390$ & 0.03 \\
\hline Pancreatic texture soft & $27(69.2 \%)$ & $54(45.4 \%)$ & 0.02 \\
\hline Pancreatic duct diameter $<3 \mathrm{~mm}$ & $9(23 \%)$ & $22(18.5 \%)$ & 0.18 \\
\hline $\begin{array}{l}\text { Type of pancreatic reconstruction } \\
\text { Pancreaticogastrostomy } \\
\text { Pancreaticojejunostomy }\end{array}$ & $\begin{array}{r}7(17.9 \%) \\
32(82.1 \%)\end{array}$ & $\begin{array}{r}16(13.4 \%) \\
103(86.6 \%)\end{array}$ & 0.60 \\
\hline $\begin{array}{l}\text { Vascular reconstruction } \\
\text { yes }\end{array}$ & $8(20.5 \%)$ & $11(9.2 \%)$ & 0.08 \\
\hline Operative time (min) & $415 \pm 125$ & $380 \pm 110$ & 0.12 \\
\hline $\begin{array}{l}\text { Operative blood loss } \\
\text { mean } \pm S D\end{array}$ & $1100 \pm 650$ & $800 \pm 500$ & 0.01 \\
\hline $\begin{array}{l}\text { Blood transfusion } \\
\text { yes }\end{array}$ & $29(74.4 \%)$ & $65(54.6 \%)$ & 0.03 \\
\hline $\begin{array}{l}\text { Pathological diagnosis } \\
\text { Malignant } \\
\text { Benign }\end{array}$ & $\begin{array}{l}26(66.7 \%) \\
13(33.3 \%)\end{array}$ & $\begin{array}{l}92(77.3 \%) \\
27(22.7 \%)\end{array}$ & 0.19 \\
\hline $\begin{array}{l}\text { Tumour differentiation in malignant cases } \\
\text { Well } \\
\text { Moderate } \\
\text { Poor }\end{array}$ & $\begin{array}{l}7(26.9 \%) \\
13(50 \%) \\
6(23.1 \%)\end{array}$ & $\begin{array}{l}17(18.5 \%) \\
50(54.3 \%) \\
25(27.2 \%)\end{array}$ & 0.36 \\
\hline $\begin{array}{l}\text { Maximum tumour diameter } \\
\text { Mean } \pm \text { SD }\end{array}$ & $2.9 \pm 2.4$ & $3.1 \pm 2.5$ & 0.28 \\
\hline $\begin{array}{l}\text { Positive LNs } \\
\text { yes }\end{array}$ & $15 / 26(57.7 \%)$ & $39 / 92(42.4 \%)$ & 0.04 \\
\hline
\end{tabular}

WI (14.9\% vs $8.7 \%$, respectively) (17). The average incidence of $\mathrm{WI}$ in some literature studies was $5.5 \%$ $21.5 \%(22,24)$.

In contrast to previous studies, Van der Gaag et al, reported in their randomized controlled trial that the incidence of severe complications was $74 \%$ in patients with endostenting versus $39 \%$ in patients with early surgery without PBD, but most of these complications were due to the procedure of ERCP, not to postsurgical complications (3). Also, $\mathrm{Ng}$ et al, reported a high incidence of overall infectious complications in the group of PBD than the other group without drainage ( $77 \%$ versus $67 \%$, respectively). Wound infection was the highest complication (41\%) of the infectious ones, followed by IAA (29\%) (16), as observed in our study. But we had a lower incidence of infectious complications than the former study.

The optimal duration of BD before PD is still unclear. In one of the animal studies, the optimal time for restoration of most of the hepatic functions, biliary epithelium and immune system functions was 4-6 weeks, even if bilirubin has decreased to its normal 
levels before this duration. So the short period of PBD may be the cause of failure of biliary stenting to improve the outcome after the operation. Also, the long duration of biliary stenting has its drawbacks of increased liability of repeated attacks of cholangitis, bacterial colonization, inflammation and fibrosis in the wall of the bile duct with a subsequent more difficult operation and a higher incidence of biliary leakage $(15,25)$. Many studies observed polymicrobial organisms in bile cultures withdrawn during the surgery in patients with biliary stenting. E-coli and Klebsiellapneumoniae were the most common bacterial infection $(16,26)$ as reported in our study. Other large volume studies are needed for the justification of the optimal time of PD needed before surgery to have a better outcome.

Another debatable issue is the best method of BD: whether internal by endoscopy or external by PTD. Kitahata et al, reported that PTD has the least postoperative complications than ENBD and ERCP. But PTD has its disadvantages of stent displacement or external tube traction by the patient, and a relative risk of increased tumour seedling (27). One of meta-analysis discussed the complication of ERCP that was used for PBD and demonstrated that $27.4 \%$ of the patients had complications related to the procedure and may be the cause of the surgical delay, and $33.8 \%$ had stent dysfunction prior to PD and most of them needed stent replacement $(13,14)$. We had nearly percentages of ERCP complications as seen in the previous study. Also, the type of the stent either plastic or covered metallic stent may affect the outcome, with better results for the metallic stent for long waiting before PD as in patients with neoadjuvant chemotherapy $(28,29)$.

\section{CONCLUSION}

In conclusion, patients with PBD still have the risk of ERCP complications that may delay the time of elective surgery. PBD had significantly higher incidence of major postoperative morbidity mainly of infectious complications and higher hospital mortality. PBD should be performed only in selected patients as in cases with cholangitis or sever hyperbiliubinemia not as a routine before PD. Preoperative high bilirubin level is not a risk factor for postoperative complications and should not be a contraindication for surgery.

Financial support: no.

Conflicts of interest: no conflicts of interest.

\section{REFERENCES}

1. Zhang GQ, Li Y, Ren YP, Fu NT, Chen HB, Yang JW, et al. Outcomes of preoperative endoscopic nasobiliary drainage and endoscopic retrograde biliary drainage for malignant distal biliary obstruction prior to pancreaticoduodenectomy. World J Gastroenterol. 2017; 23(29):5386-5394. doi: 10.3748/wjg.v23.i29.5386.

2. Sauvanet A, Boher JM, Paye F, Bachellier P, Sa Cuhna A, Le Treut YP, et al. French Association of Surgery. Severe jaundice increases early severe morbidity and decreases long-term survival after pancreaticoduodenectomy for pancreatic adenocarcinoma. J Am Coll Surg. 2015; 221(2):380-9. doi: 10.1016/j.jamcollsurg.2015.03.058.

3. van der Gaag NA, Rauws EA, van Eijck CH, Bruno MJ, van der Harst $\mathrm{E}$, Kubben FJ, et al. Preoperative biliary drainage for cancer of the head of the pancreas. N Engl J Med. 2010;362(2):129-37. doi: 10.1056/NEJMoa0903230.

4. Barauskas G, Urbonas K, Smailyte G, Pranys D, Pundzius J, Gulbinas A. Preoperative endoscopic biliary drainage may negatively impact survival following pancreatoduodenectomy for ampullary cancer. Dig Surg. 2016;33(6):462-9. doi: 10.1159/000445777.

5. Fujii T, Yamada S, Suenaga M, Kanda M, Takami H, Sugimoto H, et al. Preoperative internal biliary drainage increases the risk of bile juice infection and pancreatic fistula after pancreatoduodenectomy: a prospective observational study. Pancreas. 2015;44(3):465-70. doi: 10.1097/MPA.0000000000000265.

6. Sasahira N, Hamada T, Togawa 0, Yamamoto R, Iwai T, Tamada K, et al. Multicenter study of endoscopic preoperative biliary drainage for malignant distal biliary obstruction. World J Gastroenterol. 2016; 22(14):3793-802. doi: 10.3748/wjg.v22.114.3793.

7. Miura F, Sano K, Wada K, Shibuya M, Ikeda Y, Takahashi K, et al. Prognostic impact of type of preoperative biliary drainage in patients with distal cholangiocarcinoma. Am J Surg. 2017;214(2):256-261. doi: 10.1016/..amjsurg.2017.01.010. Epub 2017 Jan 10.

8. Inamdar S, Slattery E, Bhalla R, Sejpal DV, Trindade AJ. Comparison of adverse events for endoscopic vspercutaneous biliary drainage in the treatment of malignant biliary tract obstruction in an inpatient national cohort. JAMA Oncol. 2016;2(1):112-7. doi: 10.1001/jamaoncol.2015.3670.

9. Dindo D, Demartines N, Clavien PA. Classification of surgical complications: a new proposal with evaluation in a cohort of 6336 patients and results of a survey. Ann Surg. 2004;240(2):205-13.

10. Bassi C, Marchegiani G, Dervenis C, Sarr M, Hilal MA, Adham M, et al. The 2016 update of the International Study Group (ISGPS) definition and grading of postoperative pancreatic fistula: 11 years after. Surgery. 2017;161(3):584-591. doi: 10.1016/j.surg.2016. 11.014. Epub 2016 Dec 28.

11. Wente MN, Bassi C, Dervenis C, Fingerhut A, Gouma DJ, Izbicki JR, et al. Delayed gastric emptying (DGE) after pancreatic surgery: a suggested definition by the International Study Group of Pancreatic Surgery (ISGPS). Surgery. 2007;142(5):761-8.

12. Wente MN, Veit JA, Bassi C, Dervenis C, Fingerhut A, Gouma DJ, et al. Postpancreatectomy hemorrhage (PPH): an International Study Group of Pancreatic Surgery (ISGPS)definition. Surgery. 2007; 142(1):20-5.

13. Jinkins LJ, Parmar AD, Han Y, Duncan CB, Sheffield KM, Brown KM, et al. Current trends in preoperative biliary stenting in pancreatic cancer patients. Surgery. 2013;154(2):179-89. doi: 10.1016/j.surg. 2013.03.016.

14. Chen Y, Ou G, Lian G, Luo H, Huang K, Huang Y. Effect of preoperative biliary drainage on complications following pancreatoduodenectomy: a meta-analysis. Medicine (Baltimore). 2015;94(29):e1199. doi: 10.1097/MD.0000000000001199.

15. van der Gaag NA, Kloek JJ, de Castro SM, Busch OR, van Gulik TM, Gouma DJ. Preoperative biliary drainage in patients with obstructive jaundice: history and current status. J Gastrointest Surg. 2009;13(4): 814-20. doi: 10.1007/s11605-008-0618-4. Epub 2008 Aug 23.

16. $\mathrm{Ng} Z \mathrm{Z}$, Suthananthan $\mathrm{AE}$, Rao S. Effect of preoperative biliary stenting on post-operative infectious complications in pancreaticoduodenectomy. Ann Hepatobiliary Pancreat Surg. 2017;21(4):212216. doi: 10.14701/ahbps.2017.21.4.212. Epub 2017 Nov 30.

17. Liu C, Lu JW, Du ZQ, Liu XM, Lv Y, Zhang XF. Association of pre- 
operative biliary drainage with postoperative morbidity after pancreaticoduodenectomy. Gastroenterol Res Pract. 2015;2015:796893. doi: 10.1155/2015/796893. Epub 2015 Dec 22.

18. Smith RA, Dajani K, Dodd S, Whelan P, Raraty M, Sutton R, et al. Preoperative resolution of jaundice following biliary stenting predicts more favourable early survival in resected pancreatic ductal adenocarcinoma. Ann Surg Oncol. 2008;15(11):3138-46. doi: 10.1245/s 10434-008-0148-z. Epub 2008 Sep 12.

19. Qiu YD, Bai JL, Xu FG, Ding YT. Effect of preoperative biliary drainage on malignant obstructive jaundice: a meta-analysis. World J Gastroenterol. 2011;17(3):391-6. doi: 10.3748/wjg.v17.i3.391.

20. Garcea G, Chee W, Ong SL, Maddern GJ. Preoperative biliary drainage for distal obstruction: the case against revisited. Pancreas. 2010;39(2):119-26. doi: 10.1097/MPA.0b013e3181bd65de.

21. Morris-Stiff G, Tamijmarane A, Tan YM, Shapey I, Bhati C, Mayer AD, et al. Pre-operative stenting is associated with a higher prevalence of post-operative complications following pancreatoduodenectomy. Int J Surg. 2011;9(2):145-9. doi: 10.1016/j.ijsu.2010.10.008. Epub 2010 Oct 25.

22. Singhirunnusorn J, Roger L, Chopin-Laly X, Lepilliez V, Ponchon T, Adham M. Value of preoperative biliary drainage in a consecutive series of resectable periampullary lesions. From randomized studies to real medical practice. Langenbecks Arch Surg. 2013;398(2):295302. doi: 10.1007/s00423-012-1000-2. Epub 2012 Sep 25.

23. Maipadam JM, Mahesh S, Kadamapuzha JM, Ramesh H. The effect of preoperative biliary and pancreatic drainage on postoperative pancreatic fistula: A retrospective cohort study. Surg J (N Y). 2018; 4(1):e37-e42. doi: 10.1055/s-0038-1639343. eCollection 2018 Jan.
24. Zhao XQ, Dong JH, Jiang K, Huang XQ, Zhang WZ. Comparison of percutaneous transhepatic biliary drainage and endoscopic biliary drainage in the management of malignant biliary tract obstruction: $\mathrm{A}$ meta-analysis. Dig Endosc. 2015;27(1):137-45. doi: 10.1111/ den.12320. Epub 2014 Sep 24.

25. Lai EC, Lau SH, Lau WY. The current status of preoperative biliary drainage for patients who receive pancreaticoduodenectomy for periampullary carcinoma: a comprehensive review. Surgeon. 2014; 12(5):290-6. doi: 10.1016/j.surge.2014.02.004. Epub 2014 Mar 17.

26. Gavazzi F, Ridolfi C, Capretti G, Angiolini MR, Morelli P, Casari E, et al. Role of preoperative biliary stents, bile contamination and antibiotic prophylaxis in surgical site infections after pancreaticoduodenectomy. BMC Gastroenterology 2016;16(1):43.

27. Kitahata Y, Kawai M, Tani M, Hirono S, Okada KI, Miyazawa M, et al. Preoperative cholangitis during biliary drainage increases the incidence of postoperative severe complications after pancreaticoduodenectomy. Am J Surg. 2014;208(1):1-10. doi: 10.1016/j.amjsurg.2013.10.021. Epub 2014 Jan 17.

28. Cavell LK, Allen PJ, Vinoya C, Eaton AA, Gonen M, Gerdes H, et al. Biliary self-expandable metal stents do not adversely affect pancreaticoduodenectomy. Am J Gastroenterol. 2013;108(7):1168-73. doi: 10.1038/aig.2013.93. Epub 2013 Apr 2

29. Siddiqui AA, Mehendiratta V, Loren D, Kowalski T, Fang J, Hilden $\mathrm{K}$, et al. Self-expanding metal stents (SEMS) for preoperative biliary decompression in patients with resectable and borderlineresectable pancreatic cancer: outcomes in 241 patients. Dig Dis Sci. 2013;58(6): 1744-50. doi: 10.1007/s10620-012-2482-z. Epub 2012 Nov 21. 